\title{
MENGUNGKAP PRAKTIK SENJANGAN ANGGARAN PADA ORGANISASI NIRLABA: BADAN PENGELOLA DANA AMANAT (STUDI ETNOMETODOLOGI)
}

\author{
Tsani Aji Novarima \\ Unti Ludigdo \\ Yeney W. Prihatiningtias \\ Universitas Brawijaya \\ tsaninov@gmail.com
}

\begin{abstract}
The purpose of this study is to understand how budgetary slack occurs in operational funds of the Badan Pengelola Dana Amanat which is a non-profit organization. This research uses qualitative research method interpretive with etnometodology approach. Data collection was conducted through interviews with key informants who have roles in the Tim Penyusun Rencana Kerja Anggaran Tahunan (RKAT). The results show that budgetary participation in the process of budgeting operational funds encourages individuals to commit budgetary slack. Budgetary slack are made by individuals by targeting lower membership coverage than actual potential, and calculating higher operational costs than necessary ones. This study proves that non-profit organizations are not sterile from budgetary slack.
\end{abstract}

\section{Keywords:}

Budgetary participation; budgetary slack; ethnometodology; Badan Pengelola Dana Amanat

Anggaran diperlukan organisasi tidak semata-mata untuk mengalokasikan sejumlah uang yang diperlukan untuk menggerakan aktivitas organisasi, tetapi anggaran diperlukan sebagai alat manajemen untuk perencanaan, koordinasi dan pengendalian. Menurut Nasehatun (1999), anggaran mempunyai hubungan yang erat dengan 3 (tiga) fungsi manajemen yaitu fungsi perencanaan (planning), fungsi koordinasi (coordinating), dan fungsi pengendalian (control). Anggaran sebagai fungsi perencanaan dapat dimaknai bahwa setiap organisasi mempunyai tujuan yang hendak dicapai, baik tujuan bersifat jangka pendek maupun jangka panjang. Untuk mencapai tujuannya tersebut, organisasi perlu menetapkan kebijakan yang berisi rencana kegiatan yang diikuti dengan dana yang dibutuhkan untuk menjalankan kegiatan tersebut. Ini artinya anggaran mempunyai fungsi perencanaan. Anggaran sebagai fungsi koordinasi mempunyai arti bahwa anggaran melihat organisasi secara utuh, artinya segala kegiatan organisasi harus tercermin dalam anggaran organisasi agar dapat terkoordinasikan dengan baik dan untuk menghindari tumpang tindih anggaran atau keuangan organisasi. Dengan demikian, anggaran berperan dalam fungsi koordinasi dalam organisasi. Anggaran sebagai fungsi pengendalian berarti anggaran mempunyai fungsi untuk mengendalikan aktivitas organisasi dan biaya yang dikeluarkan oleh organisasi agar sumber daya yang dimiliki organisasi dapat dimanfaatkan sesuai dengan yang direncanakan. Organisasi perlu melakukan kegiatan monitoring dan evaluasi untuk mengetahui kesesuaian antara pelaksanaan anggaran (budget executing) dan anggaran. Perbandingan tersebut diperlukan untuk memastikan bahwa tidak ada penyimpangan anggaran.

Anggaran juga dipahami sebagai alat untuk mencapai tujuan organisasi dengan merencanakan alokasi sumber daya keuangan untuk mendukung aktivitas-aktivitas organisasi dalam jangka waktu tertentu. Anggaran yang baik dapat menyelaraskan antara tujuan organisasi, strategi yang telah ditetapkan pimpinan, dan kegiatan yang dilakukan oleh unit-unit di tubuh organisasi. Oleh karena itu, dalam jangka waktu tertentu, aktivitas organisasi dapat dilakukan sesuai dengan yang telah direncanakan dan dapat mencapai tujuan organisasi. Sebaliknya, anggaran 
yang kurang atau berlebihan menggambarkan perencanaan aktivitas yang tidak disusun secara tepat dan berpotensi untuk dilakukan revisi atau perbaikan (Stoner dan Wankel, 2003).

Di banyak organisasi, pimpinan melibatkan jajaran di bawahnya dalam menyusun anggaran. Keterlibatan bawahan dalam penyusunan anggaran dikarenakan bawahan dianggap lebih mengetahui aktivitas di unit yang menjadi tanggung jawabnya secara langsung dibandingkan dengan pimpinan. Keterlibatan ini lazim disebut partisipasi anggaran. Menurut Brownnell (1982), partisipasi anggaran merupakan upaya pimpinan melibatkan manajer dalam proses pencapaian target anggaran organisasi. Partisipasi anggaran merupakan bagian dari gaya kepemimpinan yang melibatkan manajer dalam pengambilan keputusan mengenai anggaran organisasi. Pimpinan mengharapkan adanya pengaruh terhadap kinerja manajer ketika mereka dilibatkan dalam proses penyusunan anggaran. Anggaran bisa juga dijadikan sebagai ukuran kriteria kinerja manajer dalam memenuhi kepentingan pimpinan yang "dipaksakan" melalui anggaran (Schiff dan Lewin, 1970). Namun demikian, partisipasi bawahan dalam menentukan anggaran membuka peluang bawahan untuk menentukan jumlah anggaran sesuai dengan kepentingan mereka.

Ketika kepentingan pribadi manajer masuk dalam penyusunan anggaran, anggaran yang disusun pun tidak lagi objektif alias menjadi bias. Anggaran yang pada dasarnya merupakan suatu estimasi akan aktivitas-aktivitas masa mendatang dapat dimanfaatkan oleh manajer untuk memasukan informasi yang mengandung unsur kepentingan pribadi manajer. Anggaran bias mencerminkan adanya gap antara proposal anggaran dengan kebutuhan anggaran sebenarnya atau senjangan anggaran (Lukka, 1988).

Senjangan anggaran dapat juga sengaja diciptakan oleh manajer dengan membuat target anggaran yang mudah tercapai. Ini dimaksudkan agar manajer dapat dengan mudah memenuhi target anggaran sehingga dapat memperoleh penilaian kinerja yang baik dari pimpinan. Pimpinan akan menilai bahwa manajer mempunyai kemampuan, motivasi, dan kompetensi di bidang yang menjadi tanggung jawabnya, tanpa mengetahui adanya deviasi yang diciptakan oleh manajer dalam penyusunan anggaran agar mudah tercapai (Wibowo, 2007). Kondisi ini akan menghasilkan reward yang diharapkan. Kondisi ini tentunya merupakan keuntungan bagi manajer yang memang aktif terlibat dan mempunyai pengaruh terhadap penyusunan anggaran (Brownnell, 1982). Reward dari pimpinan - bisa berupa kompensasi, peringkat jabatan, promosi, atau penggajian - menjadi tujuan individu manajer yang terlibat dalam penyusunan anggaran. Senjangan anggaran yang menghasilkan anggaran yang mudah dicapai dan bersifat menghindari risiko, telah mengantarkan pada penilaian bahwa kontribusi manajer melalui tercapainya target anggaran telah membantu organisasi mencapai tujuannya. Dengan demikian, manajer tersebut (tampak) pantas memperoleh reward.

Penelitian yang dilakukan Lukka (1988) juga menunjukkan bahwa adanya kepentingan manajer agar kinerjanya dinilai baik mendorong manajer untuk membuat anggaran yang mudah untuk dicapai sehingga proposal anggaran yang dibuat tidak sesuai dengan estimasi anggaran yang sebenarnya. Senada dengan penelitian tersebut, Young (1985) menemukan bukti bahwa senjangan anggaran merupakan upaya manajer mengecilkan kemampuan produktifnya ketika diberi kesempatan memilih standar kerja untuk mengurangi risiko ketika kinerjanya dievaluasi. Kesempatan untuk menentukan kinerjanya sendiri digunakan manajer untuk memilih standar kerja yang aman untuk menghindari risiko saat dilakukan penilaian kinerja mereka melalui mekanisme evaluasi. Penelitian Lukka (1988) dan Young (1985) makin menguatkan pendapat Brownnell (1982) di atas bahwa kepentingan untuk memperoleh penilaian kinerja yang baik dari pimpinan memotivasi manajer untuk menciptakan senjangan anggaran.

Asimetri informasi adalah faktor lain yang dapat menimbulkan senjangan anggaran. Asimetri informasi terjadi karena adanya perbedaan kualitas informasi yang dimiliki antara pimpinan dan manajer atau manajer tingkat atas dengan manajer tingkat menengah atau bawah. Manajer mempunyai informasi yang lebih daripada pimpinan mengenai aktivitas di unit yang menjadi tanggung jawabnya. Informasi bias dari manajer sangat berpotensi menimbulkan senjangan anggaran di mana manajer memberikan estimasi biaya yang terlalu tinggi dan estimasi 
pendapatan yang terlalu rendah untuk memenuhi kepentingan pribadinya. Pengaruh asimetri informasi pada senjangan anggaran adalah substansial dan dapat menyebabkan peningkatan senjangan karena penyusunan anggaran didasarkan pada informasi yang berbeda dari kenyataan (Faria dan Silva, 2013).

Penelitian yang dilakukan Maharani dan Ardiana (2015) menunjukkan adanya pengaruh asimetri informasi terhadap terjadinya senjangan anggaran pada organisasi secara signifikan. Penelitian tersebut menunjukkan bahwa semakin tinggi manajer menguasai dan memahami bidang pekerjaannya, maka potensi senjangan anggaran akan semakin tinggi. Penelitian lain yang dilakukan oleh Hariningtyas dan Aisyah (2015) juga menunjukkan hasil serupa di mana manajer memiliki kecenderungan yang tinggi untuk melakukan senjangan anggaran pada kondisi asimetri informasi yang tinggi.

Senjangan anggaran juga terkait dengan isu etika. Potensi manajer untuk menyampaikan informasi yang tidak sebenarnya yaitu anggaran biaya yang lebih tinggi dan pendapatan yang lebih rendah dari yang seharusnya, untuk kepentingan pribadi sangat terbuka. Manajer yang lebih rendah umumnya tidak mau terbuka dengan atasannya dalam penyampaian seluruh informasi yang dimiliki sehingga atasan memperoleh gambaran akan potensi yang tereduksi. Kesalahan pengalokasian yang disengaja oleh manajer merupakan bagian dari masalah etika dalam sebuah organisasi (Douglas dan Wier, 2000). Salah satu aspek etika dalam anggaran adalah adanya perilaku yang menyimpang dalam penyusunan anggaran. Perilaku yang menyimpang bisa menjadi penyebab senjangan anggaran karena dapat mengarahkan proses anggaran pada hasil yang tidak diharapkan (Liza, Jamil, dan Nor, 2013). Perilaku menyimpang akan membawa konsekuensi yang negatif bagi individu-individu atau organisasi karena dapat memicu timbulnya konflik dalam organisasi (Griffin dan Lopez, 2005).

Senjangan anggaran juga terjadi pada sektor publik atau lembaga nirlaba. Penelitian yang dilakukan oleh Jaya (2012) menunjukkan bahwa asimetri informasi mempunyai pengaruh yang signifikan terhadap senjangan anggaran pada Pemerintah Kota Pasuruan. Manajer yang mempunyai informasi detail mengenai teknis pekerjaan dan aktivitas yang menjadi tanggung jawabnya tidak memberikan informasi tersebut kepada atasannya sehingga atasan tidak memiliki akses terhadap informasi yang lengkap dan sebenarnya.

Hasil penelitian tersebut sesuai dengan penelitian Young (1985) di mana manajer akan cenderung merahasiakan informasi yang relevan dalam penyusunan anggaran sehingga memicu terjadinya senjangan anggaran. Adapun Setyorini (2013) menemukan senjangan anggaran terjadi di organisasi nirlaba, yaitu Universitas Kristen Satya Wacana (UKSW) Salatiga. Senjangan anggaran di UKSW Salatiga dilakukan dengan meninggikan anggaran pendapatan dan biaya dari estimasi terbaik. Anggaran pendapatan ditinggikan dengan cara meningkatkan jumlah mahasiswa, sedangkan anggaran biaya dibuat tinggi melalui pembuatan program kerja yang banyak. Motivasi karyawan melakukan senjangan anggaran adalah bonus.

Sebagai sebuah entitas yang diamanahi menyelenggarakan jaminan sosial, Badan Pengelola Dana Amanat membutuhkan dana operasional untuk peningkatan kualitas layanan kepada peserta. Dana operasional Badan Pengelola Dana Amanat bersumber dari dana jaminan sosial/dana publik. Senjangan anggaran pada dana operasional Badan Pengelola Dana Amanat, menurut peneliti, tidak bisa dihindari. Senjangan anggaran tersebut menarik untuk dipahami lebih jauh karena melibatkan dana publik yang tidak sedikit. Tujuan utama penelitian ini adalah mengkaji pola praktik antar individu dalam penyusunan anggaran yang menimbulkan senjangan anggaran pada dana operasional Badan Pengelola Dana Amanat. Dalam rangka mencapai tujuan utama penelitian tersebut peneliti berkeinginan memahami landasan berpikir individu-individu dalam menyusun anggaran sehingga terjadi senjangan anggaran pada dana operasional Badan Penyelenggara Jaminan Ketenagakerjaan. 


\section{METODE}

Untuk mencapai tujuan penelitian tersebut, penelitian ini menggunakan paradigma interpretif dengan pendekatan etnometodologi untuk menganalisis isu senjangan anggaran. Penelitian ini memfokuskan pada eksplorasi pemahaman atas realitas senjangan anggaran pada dana operasional Badan Pengelola Dana Amanat. Etnometodologi merupakan bagian dari rumpun penelitian kualitatif yang menggunakan latar alamiah di mana pengamatan atas perilaku, persepsi, motivasi, tindakan subjek penelitian akan dideskripsikan dalam bentuk kata-kata atau bahasa (Moleong, 1989, 4). Latar alamiah merupakan lingkungan sosial yang menyimpan informasi atas fenomena yang akan diungkap atau tidak diungkap oleh peneliti (Maykut dan Morehouse, 1994). Latar ilmiah menjadi bagian penting penelitian kualitatif karena penelitian kualitatif bertujuan memahami aspek-aspek kehidupan sosial di mana peneliti akan mengobservasi, menjelaskan, dan menginterpretasikan pengalaman dan perilaku dari individu atau komunitas sosial dalam konteks sosial atau budaya (Lincoln dan Guba, 1985).

Dengan pendekatan etnometodologi, peneliti dapat memahami aktivitas sehari-hari yang dilakukan oleh individu-individu dalam suatu komunitas, yaitu Badan Pengelola Dana Amanat, khususnya individu-individu yang terlibat dalam menyusun anggaran dana operasional. Etnometodologi melihat realita sosial sebagai suatu kondisi yang cair, tidak tetap atau tidak stabil. Atau dengan kata lain, realita sosial yang terbentuk dipengaruhi oleh lingkungan sekitar (Kamayanti, 2016). Karena kondisi yang cair tersebut, peneliti mengungkap makna sosial sebagai suatu proses yang berkelanjutan dalam suatu komunitas. Untuk alasan ini, peneliti menganalisis pengalaman-pengalaman informan di lapangan. Ada semacam pemahaman bahwa suatu komunitas mempunyai penalaran tertentu dengan menerapkan aturan sosial secara implisit atau diam-diam. Etnometodologi berupaya mengungkapkan aturan tak tertulis yang diikuti oleh anggota komunitas tanpa disadari secara eksplisit. Dengan mempelajari interaksi sosial yang terbentuk dalam suatu komunitas, peneliti berusaha mengidentifikasikan nilai-nilai sosial yang terbentuk dan komunitas tersebut dan bagaimana mereka menerapkan nilai-nilai sosial tersebut (Neuman, 2003).

Penyusunan dana operasional Badan Pengelola Dana Amanat telah berlangsung selama 4 tahun dan menjadi sesuatu yang rutin dilakukan setiap tahun. Persiapan penyusunan anggaran dana operasional dilakukan jauh-jauh hari sebelum tahun anggaran berjalan dimulai. Ini artinya penyusunan anggaran dana operasional dilakukan dalam suatu rutinitas. Rutinitas tersebut tentunya telah menciptakan dinamika di komunitas penyusun-penyusun anggaran di Badan Penyelenggara Jaminan Sosial tentang bagaimana cara menyusun anggaran sesuai dengan yang mereka harapkan. Rutinitas yang menghasilkan kesepakatan-kesepakatan tersebut menciptakan pemahamanpemahaman di antara penyusun anggaran dalam menyelesaikan persoalan.

Pemahaman di antara para penyusun anggaran dana operasional tersebut menarik untuk diteliti lebih dalam. Dengan etnometodologi, peneliti dapat memahami fakta-fakta sosial yang muncul di antara penyusun anggaran dana operasional dan penalaran atas realitas hidup mereka sehingga tampak rasional, dapat diterangkan, dan tidak meragukan (Ahmadi, 2014). Etnometodologi akan membantu peneliti untuk mengetahui bagaimana para penyusun anggaran dana operasional Badan Pengelola Dana Amanat menciptakan dan memahami pekerjaan sehari-hari mereka dan cara mereka menyelesaikan persoalan dana operasional Badan Pengelola Dana Amanat. Dengan demikian, dengan menggunakan pendekatan etnometodologi, penelitian ini diharapkan dapat mendekatkan dengan praktek-praktek penyusunan anggaran dana operasional Badan Pengelola Dana Amanat.

Analisis indeksikalitas dan refleksivitas adalah ciri dari pendekatan etnometodologi. Analisis indeksikalitas merupakan proses menemukan kata-kata atau ungkapan-ungkapan yang mengacu pada individu, waktu, dan tempat tertentu. Analisis refleksivitas adalah penerjemahan indeksikalitas tersebut dalam interaksi antar individu di komunitas, sehingga indeks yang muncul dapat dipahami. Analisis refleksivitas dalam penelitian ini akan menelaah dan menjabarkan ekspresi indeksikalitas tersebut, termasuk menemukan ungkapan atau tema yang tidak menarik namun relevan dengan penelitian ini (Garfinkel, 1967). 
Informan dalam penelitian ini berjumlah 3 orang sebagai informan kunci yang semuanya berperan serta dalam Tim Penyusun Rencana Kerja Anggaran Tahunan (RKAT). Lima informan kunci tersebut adalah: 1) Bapak J selaku Direktur Perencanaan, 2) Bapak T selaku Kepala Urusan Anggaran, 3) Mas I selaku Kepala Urusan Data dan Informasi Jaminan Sosial Ketenagakerjaan. Para informan tersebut sangat menguasai dan berpengalaman dalam proses penyusunan anggaran dana operasional. Penguasaan dan pengalaman dalam penyusunan anggaran dana operasional sangat peneliti butuhkan untuk tujuan penelitian. Hal ini sesuai dengan karakteristik penelitian kualitatif yang menggunakan purposive sampling dimana informan yang dipilih harus benar-benar kaya informasi dan/atau menjadi pelaku dari fakta sosial yang sedang diteliti (Ahmadi, 2014).

Penelitian ini dilakukan selama kurang lebih 1,5 bulan di Kantor Pusat Badan Sosial "Pekerja Sosial" yang berlokasi di DKI Jakarta. Peneliti berusaha membaur dengan para informan agar terjalin suasana yang cair sehingga wawancara atau diskusi dapat dilakukan dalam suasana yang tidak kaku. Proses wawancara dilakukan di beberapa lokasi yaitu di ruang kerja informan, di ruang istirahat, di perpustakaan, dan di rumah makan.

\section{HASIL DAN PEMBAHASAN}

Anggaran sangat lekat dengan angka-angka, estimasi, dan sangat terkait dengan keuangan. Namun tidak dapat dipungkiri bahwa dibalik itu, ada unsur manusia yang mempunyai peran penting dalam penyusunan anggaran. Manusia yang menyusun anggaran, manusia pula yang akan menggunakan dan mempertanggungjawabkannya. Oleh karena peran manusia dalam anggaran, anggaran tidak bisa dilepaskan dari perilaku manusia dan nilai-nilai yang mendasarinya. Aspek perilaku ini akan mempengaruhi manusia yang terlibat dalam penyusunan anggaran. Anggaran tidak sekadar menyajikan angka-angka dalam kurun waktu tertentu, tetapi ada sisi lain dalam suatu anggaran yaitu bagaimana manusia menyusun suatu anggaran dalam organisasi.

Senjangan anggaran merupakan salah satu produk dari perilaku manusia dalam menyusun anggaran. Perilaku anggaran bisa mewujud dalam bentuk apapun yang dilakukan oleh manusia terkait dengan anggaran. Behavior is anything that a person does (Gibson, Ivancevich, Donnelly, dan Konopaske, 2012). Dalam konteks perilaku yang menciptakan senjangan anggaran, perilaku ini bisa berupa memasukan kepentingannya dalam angka, mengakomodasi motivasi dalam estimasi, dan mencapai keinginan melalui anggaran. Berdasarkan hasil penelitian ini, senjangan anggaran pada dana operasional Badan Pengelola Dana Amanat juga terjadi karena perilaku para aktor yang menyusun anggaran. Seperti yang disampaikan oleh Ajibolade dan Akinniyi (2013) bahwa senjangan anggaran pada suatu organisasi tidak hanya dilihat dari aspek ekonomi saja, tetapi juga dilihat dari aspek sosial, perilaku, maupun manajerial dalam konteks organisasi secara keseluruhan.

\section{Penyusunan Anggaran Dana Operasional: Sebuah Partisipasi Anggaran}

Penyusunan anggaran dana operasional Badan Pengelola Dana Amanat melibatkan banyak pihak dari tingkat direksi sampai dengan tingkat staf, dari level pusat sampai level kantor cabang. Keterlibatan kantor wilayah atau cabang dalam penyusunan anggaran didasari pada alasan logis bahwa mereka yang lebih paham mengenai potensi yang ada di wilayah kerjanya. Potensi kepesertaan yang terdapat pada kantor wilayah atau kantor cabang akan mempengaruhi besar kecilnya dana yang akan diterima dalam rangka mencapai target kepersertaan.

Unit kerja yang ada di kantor pusat Badan Pengelola Dana Amanat juga terlibat dalam penyusunan anggaran dana operasional karena mereka berperan dalam menghasilkan suatu kebijakan penyelenggaraan jaminan sosial. Dengan peran tersebut, unit kerja kantor pusat Badan Pengelola Dana Amanat mempunyai kegiatan non pelayanan. Kegiatan-kegiatan yang dilakukan oleh unit kerja kantor pusat antara lain rapat koordinasi, bimbingan teknis, pengawasan, menyusun aturan teknis, dan pembinaan ke kantor wilayah atau kantor cabang.

Keterlibatan para aktor dalam penyusunan anggaran dana operasional Badan Pengelola Dana Amanat, diawali ketika Direksi membentuk Tim Penyusun Rencana Kerja Anggaran Tahunan (RKAT) setiap tahun yang ditetapkan dengan Surat Perintah Direktur Utama Badan 
Pengelola Dana Amanat. Keterlibatan beberapa pihak tersebut menunjukkan bahwa Direksi menginginkan adanya keterlibatan level di bawahnya (Kepala Divisi/Kepala Wilayah/Kepala Cabang/Staf) dalam menyusun anggaran dana operasional Badan Pengelola Dana Amanat.

Model kepemimpinan Direksi Badan Pengelola Dana Amanat tersebut di atas adalah upaya Direksi melibatkan jajaran di bawahnya dalam proses pencapaian target anggaran organisasi. Direksi mengharapkan adanya pengaruh terhadap kinerja jajaran di bawahnya ketika mereka dilibatkan dalam proses penyusunan anggaran dana operasional. Keterlibatan beberapa pihak ini dikonfirmasi oleh informan Bapak J.

"Di tim itu kan kita juga ada beberapa kali rapat ..tim itu lintas departemen...jadi ada lintas divisi, lintas direktorat eee...hampir seluruh divisi lah kalau dari ini karena semua menyangkut ..kecuali untuk yang di cabang, kanwil...biasanya kita pilih saja yang terdekat...tidak semua karena costnya mahal pada saat rapat-rapat, nah nanti ada ininya juga pas kita surati mereka apa yang diinginkan. Terus setelah itu kita menyusun usulan RKAT dari cabang kanwil dan divisi. Jadi eee... biasanya kita akan mengirimkan surat ke cabang kanwil ke divisi tertentu, formatnya sudah bagus ..nah ini kita lakukan."

(Percakapan terjadi di ruang kerja Bapak $\mathbf{J}$ yang cukup besar dan nyaman. Bapak $\mathbf{J}$ menjelaskan dengan tenang dan sesekali diselingi senyuman. Beliau menjelaskan dengan logat jawa yang cukup medog, mengingat beliau berasal dari Wates. Peneliti sudah mengenal Bapak J sebelumnya karena pernah berada dalam satu tim pembahasan sebuah undang-undang).

Pernyataan beliau "tim itu lintas departemen...jadi ada lintas divisi, lintas direktorat eee.hampir seluruh divisi lah kalau dari ini karena semua menyangkut...kecuali untuk yang di cabang, kanwil...biasanya kita pilih saja yang terdekat" menunjukkan bahwa Direksi melibatkan jajaran di bawahnya dalam penyusunan anggaran dana operasional Badan Pengelola Dana Amanat. Keterlibatan bawahan dimaksudkan agar bawahan dapat menyampaikan usulan kegiatan-kegiatan yang diperlukan unit masing-masing. Usulan-usulan ini akan menjadi bahan menyusun Rencana Kerja Anggaran Tahunan (RKAT). Pada tahap awal, keterlibatan bawahan dalam penyusunan anggaran dana operasional diwujudkan dalam 2 bentuk yaitu keterlibatan secara langsung di mana pembahasan anggaran dilakukan melalui rapat atau pertemuan secara langsung. Pertemuan ini dikoordinasi oleh Kantor Pusat Badan Pengelola Dana Amanat. Pertemuan ini dihadiri oleh unitunit kerja di pusat dan daerah (divisi-divisi dan beberapa Kantor Wilayah dan Kantor Cabang terdekat) dengan pertimbangan faktor biaya. Yang kedua adalah keterlibatan secara tidak langsung melalui mekanisme persuratan kepada kantor wilayah atau cabang dengan format yang telah disiapkan oleh Kantor Pusat Badan Pengelola Dana Amanat. Pernyataan Bapak J tersebut di atas merefleksikan bahwa pimpinan menerapkan partisipasi anggaran dalam penyusunan dana operasional.

Keterlibatan setiap unit kerja di pusat dan daerah merupakan upaya untuk memperkuat kerja sama di internal organisasi. Kerja sama yang kuat akan menjadi modal bagi Badan Pengelola Dana Amanat untuk mencapai tujuannya yaitu memberikan pelayanan yang maksimal kepada peserta dengan menggunakan biaya yang seefisien mungkin. Keterlibatan dalam menyusun anggaran juga diharapkan mampu memberikan motivasi kepada para karyawan dengan mengakomodir usulan yang mereka bawa. Kondisi ini juga diharapkan dapat mendorong setiap unit kerja di pusat dan daerah termotivasi mencapai target yang telah ditetapkan karena mereka ikut memiliki peran dalam menentukan sasaran yang akan dicapai.

Keterlibatan unit kerja di pusat dan daerah tidak hanya pada saat penyusunan anggaran dana operasional, tetapi sudah dimulai ketika menyusun rencana strategis. Unit kerja di pusat dan daerah dapat memberikan masukan atau informasi kepada kantor pusat Badan Pengelola Dana Amanat terkait dengan target yang akan dicapai dan biaya yang akan digunakan untuk membiayai kegiatannya. 
"Waktu penyusunan renstranya itu sendiri saya rasa itu juga sudah mengakomodir dari kanwil lah minimal. Jadi untuk pembahasan Renstra itu akan inisiatif-inisiatif dari masingmasing kalau di kantor pusat, ya masing-masing direktorat, kemudian dari kanwil saya rasa, temen-temen mengakomodir itu sih."

Pernyataan Bapak $\mathrm{T}$ "Waktu penyusunan renstranya itu sendiri saya rasa itu juga sudah mengakomodir dari kanwil lah minimal." menunjukkan bahwa pimpinan sudah berusaha menampung inisiatif-inisiatif yang berasal dari unit kerja di pusat atau daerah sejak awal perencanaan, yaitu tatkala menyusun rencana strategis organisasi. Rencana Strategis merupakan panduan arah pengembangan Badan Pengelola Dana Amanat yang berisi mengenai langkahlangkah strategis yang akan dilaksanakan oleh Badan Pengelola Dana Amanat dalam kurun waktu 5 (lima) tahun. Inisiatif-inisiatif dari unit kerja di pusat dan daerah diperlukan untuk memetakan potensi dan tantangan yang akan dihadapi oleh Badan Pengelola Dana Amanat dalam kurun waktu tersebut. Dengan wilayah kerja yang mencakup seluruh Indonesia, informasi dari kantor wilayah atau kantor cabang dapat membantu kantor pusat Badan Pengelola Dana Amanat dalam menganalisis lingkungan eksternal maupun internal. Pernyataan Bapak T tersebut merefleksikan pengakomodasian inisiatif-inisiatif unit kerja di pusat dan daerah oleh kantor pusat.

Rencana Kerja Anggaran Tahunan (RKAT) merupakan turunan dari Rencana Strategis Badan Pengelola Dana Amanat. Rencana Kerja Anggaran Tahunan (RKAT) menggambarkan langkah-langkah yang akan dilakukan oleh Badan Pengelola Dana Amanat secara tahunan untuk mendukung tujuan institusi yang telah ditetapkan dalam Rencana Strategis. Penyusunan Rencana Kerja Anggaran Tahunan (RKAT) sendiri dilakukan melalui Rapat Kerja Nasional yang dihadiri seluruh level di Badan Pengelola Dana Amanat. Dalam Rapat Kerja Nasional tersebut juga akan dibahas mengenai anggaran dana operasional yang merupakan bagian dari Rencana Kerja Anggaran Tahunan (RKAT). Proses pembahasan ini diuraikan oleh informan Bapak J kepada peneliti.

"Nanti ada rakernas kita kumpulkan cabang dan kanwil di dalam rakernas...jadi dari rakernas itu ada masukan-masukan makanya kita biasanya akan sesuaikan tuh...karena di dalam rakernas juga nanti juga kita kan eee...ada semacam...misalnya terkait kepesertaan nanti ada yg membahas ini...supaya lebih fokus lagi. jadi ada komisi-komisinya gitu lah...nah setelah itu ada pembahasan dengan komite...komite yg menangani anggaran ini."

Pernyataan Bapak J "Nanti ada rakernas kita kumpulkan cabang dan kanwil di dalam rakernas..." menunjukan keterlibatan bawahan dalam penyusunan anggaran berlanjut sampai agenda Rapat Kerja Nasional. Ini berarti partisipasi anggaran yang melibatkan bawahan cukup intens. Keterlibatan semua unit hingga pada rapat teknis di Rapat Kerja Nasional mencerminkan bahwa partisipasi anggaran pada penyusunan dana operasional Badan Pengelola Dana Amanat dipandang sebagai hal yang positif. Sebagaimana dijelaskan sebelumnya, bahwa ini adalah gaya kepemimpinan yang dipilih oleh manajemen Badan Pengelola Dana Amanat. Kepemimpinan yang melibatkan unit di bawah manajemen untuk melakukan pembahasan anggaran dana operasional.

\section{Praktik Senjangan Anggaran: Mengecilkan Target, Meninggikan Biaya}

Sebagaimana dijelaskan di atas bahwa keterlibatan bawahan dalam proses penyusunan anggaran cukup intens. Konsekuensi dari partisipasi anggaran sebagaimana di atas adalah adanya potensi senjangan anggaran. Ini juga nampak ketika dalam Tim Penyusun Rencana Kerja Anggaran Tahunan (RKAT) menyadari ada anggaran yang kurang tepat. Unit kerja mengusulkan anggaran dengan prinsip "yang penting ada usulan'. Kondisi ini disampaikan oleh informan Mas I kepada peneliti.

"Kayaknya memang dari divisi mengacunya yang gede-gede, tapi mungkin yang penting usulin dulu. Kadang ada yg gak tahu...ini anggarannya biaya apa ya? oh pake ini, duitnya segini. biasa kita ngajuin ini...target dipotong...ya gitu-gitu 
aja...dipotong atau diilangin kegiatannya, dipotong dikurangin orangnya atau frekuensinya."

(Mas I menjelaskan hal tersebut dengan gaya bicara pelan-pelan. Mas I memang mengakui bahwa ketrampilan komunikasinya buruk. Itulah mengapa Mas I lebih suka dengan pekerjaan mengutak atik data atau angka daripada pekerjaan yang banyak interaksi dengan orang. Namun, kemampuannya dalam mengolah data ini membuat pimpinan secara langsung meminta Mas I masuk dalam Tim Penyusun Rencana Kerja Anggaran Tahunan (RKAT)).

Pernyataan Mas I "Kayaknya memang dari divisi mengacunya yang gede-gede, tapi mungkin yang penting usulin dulu." menunjukkan bahwa unit kerja mengusulkan anggaran yang melebihi kebutuhan. Ini sudah menjadi kebiasaan dan adakalanya tanpa mengetahui urgensi keperluan biaya yang diusulkan sendiri. Ini memunculkan potensi usulan anggaran yang tidak sesuai dengan kebutuhan sebenarnya. Memang kondisi tersebut didorong adanya asumsi atau "hukum anggaran" yang tak tertulis bahwa jatah anggaran unit yang diajukan pasti selalu kena pemotongan atau pengurangan jatah. Ada kekhawatiran apabila mengajukan usulan anggaran yang sesuai dengan kebutuhan, nantinya anggaran final malah berkurang. Pernyataan Mas I tersebut merefleksikan bahwa unit kerja memang secara sengaja menyusun anggaran melebihi kebutuhan yang sebenarnya.

Apa yang terjadi sebagaimana pernyataan Mas I mendapat pengakuan juga dari Bapak J. Bapak $\mathbf{J}$ melihat bahwa anggaran yang diusulkan dibuat tidak dengan perhitungan yang matang. Bapak J memberikan konfirmasi atas kondisi tersebut kepada peneliti.

"Nah setelah itu (usulan dari unit kerja) kita kompilasi kita kumpulkan...termasuk disitu kepesertaan misalnya...ya dia harus ini juga potensi di sana seperti apa, yang sedang digarap berapa, nanti kan mereka biasanya kan...samalah seperti di instansi yang lain kalau dari sisi target dari sisi kepesertaan di kecilin kan maunya...kalau biaya digede-gedein kan gitu..."

(Ketika menyampaikan hal tersebut, Bapak J sedikit tersenyum seolah memaklumi bahwa perilaku anggaran tersebut merupakan hal yang sudah menjadi rahasia umum).

Pernyataan Bapak J "samalah seperti di instansi yang lain kalau dari sisi target dari sisi kepesertaan di kecilin kan maunya...kalau biaya digede-gedein kan gitu" menunjukkan bahwa perilaku anggaran mengecilkan target dan meninggikan biaya dari yang seharusnya memang terjadi saat pengusulan anggaran dana operasional. Ini membuktikan bahwa partisipasi anggaran dapat mempengaruhi perilaku para aktor dalam membuat estimasi anggaran yang bias. Ini tidak lepas dari karakteristik anggaran yang berisi asumsi-asumsi di masa mendatang yang mengandung ketidakpastian. Ketidakpastian tersebut membuka peluang timbulnya anggaran bias yang terjadi karena informasi yang tidak akurat. Anggaran bias mencerminkan adanya perbedaan antara kebutuhan anggaran sebenarnya dan proposal anggaran yang diajukan oleh unit kerja di pusat dan daerah. Lukka (1988) menyebut ini sebagai bentuk senjangan anggaran. Pernyataan Bapak J merefleksikan senjangan anggaran yang dibuat oleh para aktor dengan jalan mengusulkan target yang dikecilkan dan biaya yang ditinggikan.

Kenyataan bahwa unit kerja di pusat dan daerah membuat usulan anggaran yang melenceng seperti sebuah "kesepakatan" yang diam-diam berlaku di antara para aktor. Kekompakan perilaku anggaran tersebut menjadi sebuah strategi yang selalu diterapkan setiap kali mengusulkan anggaran. Peneliti kemudian melakukan konfirmasi kepada informan Bapak T sebagai Kepala Urusan Anggaran yang sering berinteraksi secara teknis dengan usulan-usulan anggaran dari unit kerja di pusat dan daerah. Beliau tidak membantah bahwa perilaku tersebut memang benar terjadi di Badan Pengelola Dana Amanat.

"Kalau usulan ya eee...biasalah...kalau usulan target itu kanwil sampai cabang, konsolidasi kanwil biasanya under lah...hehehe...strateginya dari cabang atau kanwil asumsinya mereka aku ngajuin sekian paling nanti diup...hehehehe...ya 
mungkin di kementerian demikian kan? Kalau dari sisi biaya kan udah...hajar masuk, toh nanti juga dipotong...hehehehe..."

Pernyataan Bapak $\mathbf{T}$ tersebut senada dengan apa yang disampaikan oleh Bapak $\mathbf{J}$ di atas mengenai perilaku para pengusul anggaran dana operasional. Pernyataan "Kalau usulan target itu kanwil sampai cabang, konsolidasi kanwil biasanya under lah...hehehe... Kalau dari sisi biaya kan udah...hajar masuk, toh nanti juga dipotong...hehehehe..." menunjukkan bahwa strategi "merendahkan target dan meninggikan biaya" sudah melekat dalam penyusunan anggaran dana operasional. Strategi tersebut mengandung maksud bahwa rendahnya target kepesertaan akan membuat unit kerja tidak perlu bersusah payah dalam mencapainya, sedangkan anggaran yang tinggi akan membuat mereka leluasa dalam membuat kegiatan-kegiatan di unit kerja masingmasing. Pernyataan tersebut merefleksikan bahwa usulan anggaran belum dibuat sesuai dengan potensi capaian target dan belum sesuai dengan kebutuhan sebenarnya.

Upaya merendahkan target dan meninggikan biaya sepertinya sudah menjadi "trade mark" para penyusun anggaran. Perilaku tersebut akan muncul setiap proses penyusunan anggaran. Keterlibatan bawahan dalam proses penyusunan anggaran masih membawa estimasi yang kurang tepat kepada pimpinan yang berdampak kurang akuratnya anggaran organisasi. Sebagaimana penjelasan di atas, perkiraan bias tersebut dilakukan dengan cara memberikan data target yang rendah dan usulan biaya yang lebih besar dari pada yang seharusnya.

Dari sudut pandang suatu perencanaan, hal tersebut memang tidak serta merta dianggap sebagai suatu kesalahan yang berdampak hukum. Bahkan ketika anggaran tersebut disetujui kemudian dieksekusi oleh pengguna anggaran, hal tersebut tidak serta merta menjadi kesalahan karena akan tergantung bagaimana unit kerja mengeksekusi dan mempertanggungjawabkan anggaran. Kalau penggunaan dan pertanggungjawabannya sesuai dengan koridor aturan, anggaran tersebut secara legal bisa diterima. Akan tetapi, dari sudut pandang sosial, hal ini merupakan pelanggaran kontrak sosial, terlebih anggaran dana operasional bersumber dari dana publik yang seharusnya dijaga pemanfaatannya sejak dari proses perencanaan. Pelanggaran kontrak sosial, dalam hal ini kontrak untuk menjaga dana publik, setara dengan penyalahgunaan kewenangan yang bisa memicu terjadinya fraud (Colombatto, 2001). Dari aspek etika, perilaku anggaran tersebut merupakan bagian dari perilaku yang tidak etis. Etika dalam penganggaran akan membuat seseorang rela mengesampingkan kesejahteraan dirinya demi kejujuran dalam membuat laporan atau catatan kepada atasan mengenai potensi yang dimiliki oleh perusahaan (Stevens, 2002).

Praktik penyusunan anggaran tersebut di atas nampaknya sudah berlangsung hampir setiap tahun sebagaimana pernyataan Bapak T kepada peneliti.

"Usulan target dari cabang begitu sudah menahun...hehehe... ya fungsi kita yang ada dipusat kan ada tim RKAT itu juga kan melibatkan seluruh divisi lah untuk masalah target ada temen-temen dari kepesertaan yang untuk mengevaluasi pengajuan cabang seperti apa, kemudian yang dari kegiatan yang sifatnya strategis atau enggak itu temen2 dari pusat...itu bisa memilah"

Pernyataan Bapak $\mathrm{T}$ "Usulan target dari cabang begitu sudah menahun" menunjukkan bahwa usulan anggaran yang bias, khususnya terkait dengan target anggaran, berulang setiap tahun. Ini menggambarkan bahwa unit kerja di daerah yang merupakan ujung tombak untuk mencapai target organisasi merasa nyaman dengan usulan target yang tidak sesuai dengan potensi di daerahnya. Pernyataan Bapak $\mathrm{T}$ tersebut merefleksikan bahwa belum ada perubahan praktik anggaran sehingga anggaran bias masih terus terjadi.

Telah disebutkan di atas bahwa manusia merupakan faktor kunci dalam anggaran. Oleh karena itu, anggaran berdampak langsung terhadap manusia. Aspek perilaku yang terkait dengan anggaran merujuk pada perilaku manusia yang terlibat pada proses penyusunan anggaran. Adanya anggaran mengakibatkan manusia membatasi aktivitasnya. Anggaran pula yang menyebabkan kinerja manajer selalu dan secara kontinyu dipantau serta dibandingkan dengan standar yang telah ditetapkan. Hal ini pula yang mengakibatkan timbulnya tekanan. Manajer seringkali menghadapi 
permasalahan akibat adanya penyimpangan anggaran, seperti misalnya timbulnya over atau under budget, penyimpangan dari anggaran yang ditetapkan, dan sebagainya. Akibatnya anggaran kemudian dianggap sebagai sesuatu yang dapat menghambat atau mengancam karir. Dengan demikian anggaran mempengaruhi perilaku manusia (Rispantyo, 2010).

Ada hal yang menarik ketika Bapak J menceritakan kegiatan perjalanan dinas di institusinya. Beliau menyampaikan bagaimana unit kerja kantor pusat mempunyai anggaran perjalanan dinas yang tinggi. Beliau sempat mengusulkan agar biaya perjalanan dinas dipotong atau dilakukan perubahan mekanisme perjalanan dinas.

"Saya sampai bilang kemaren, dipotong $1 \mathrm{~T}$ (triliun) aja masih cukup. gak usah naik.

Ini kan gini Kadiv, Kaur, itu traveling tinggi sekali, menurut saya gak ini. Kalau temen-temen mau jalan itu tinggal minta aja neh dari customernya. tinggal bilang customer, tolong panggil saya dong. tapi biaya sebenernya sudah ada, maksud saya kalau itu dipotong, bahkan kalau misal oke...at cost ya, tapi banyak yang gak mau."

(Bapak J tampak semangat menjelaskan tentang kegiatan perjalanan dinas di institusinya. Obrolan berlangsung di ruang kerja Bapak J pada suatu pagi. Peneliti lebih banyak mendengarkan dengan seksama penjelasan Bapak $\mathbf{J}$ sambil sesekali peneliti menyeruput secangkir teh yang disuguhkan oleh seorang office boy)

Pernyataan Bapak J "Saya sampai bilang kemaren, dipotong $1 \mathrm{~T}$ (triliun) aja masih cukup. gak usah naik. Ini kan gini Kadiv, Kaur, itu traveling tinggi sekali" menunjukkan bahwa ada potensi senjangan anggaran pada dana operasional Badan Pengelola Dana Amanat dalam kegiatan perjalanan dinas unit kerja di pusat. Perjalanan dinas menjadi hal yang menguntungkan karena selain memperoleh tambahan penghasilan, juga bisa dimanfaatkan untuk jalan-jalan. Hal yang sepertinya umum berlaku di setiap instansi baik pemerintah maupun swasta.

Frekuensi perjalanan dinas yang dinilai terlalu tinggi memicu tingginya anggaran dana operasional untuk perjalanan dinas. Bapak $\mathrm{J}$ bahkan berani berpendapat bahwa kalau pun anggaran dipotong Rp1.000.000.000.000,-, anggaran dana operasional Badan Pengelola Dana Amanat masih mencukupi untuk mendanai kegiatan selama setahun dengan salah satu efisiensi pada perjalanan dinas. Efisiensi perjalanan dinas dilakukan dengan mekanisme at cost pada semua unsur biaya perjalanan dinas. Adapun yang dimaksud "customer" oleh Bapak J adalah kantor wilayah atau kantor cabang yang akan didatangi oleh pihak Kantor Pusat. Informan Bapak J menjelaskan lebih jauh mengenai at cost.

"At cost itu bener-bener kalau bener-bener transport, hotel, harian itu gak ada lagi.

Harian itu untuk apa? Ya makan dibayarin juga, ini pasti lebih irit. maksudnya jadi orang gak ngantongin gitu loh...kan masih ada sisa tuh kalau di sini. Nah itu sebenernya di sana sudah ada, walaupun ini bensin kan, itu pasti lebih murah lah. Itu pasti dewas sama direksi mikir-mikir, ngapain saya ke sana, capek doang, lebih kepada gimana saya melakukan pekerjaan sesuai ini, apa ini ya saya gak perlu ke sana. Kalau sekarang kan gitu, saya memaknai itu

Pernyataan Bapak J "Harian itu untuk apa? Ya makan dibayarin juga, ini pasti lebih irit. maksudnya jadi orang gak ngantongin gitu loh...kan masih ada sisa tuh kalau di sini" menunjukkan bahwa kegiatan perjalanan dinas merupakan kegiatan yang favorit (setidak-tidaknya salah satu kegiatan favorit) karena memberikan insentif yang bisa dibawa pulang oleh pegawai yang menjalankan perjalanan dinas. Sementara kondisi di lapangan, pegawai yang melaksanakan perjalanan dinas tidak mengeluarkan ongkos untuk hariannya. Tim Manajemen atau pegawai yang melakukan perjalanan dinas tidak perlu mencari-cari cara agar bisa "ngantongin" karena semua kebutuhan di tempat tujuan perjalanan dinas sudah dipenuhi. Dalam bahasa umum, kantor daerah akan menjamu full pegawai pusat yang melakukan perjalanan dinas ke daerah. Pernyataan Bapak $\mathbf{J}$ merefleksikan bahwa anggaran perjalanan dinas dimanfaatkan untuk menambah penghasilan

Menurut informan Bapak J, penerapan at cost secara menyeluruh akan berdampak pada biaya perjalanan dinas yang lebih irit. Perjalanan dinas memang benar-benar digunakan untuk 
bekerja dan tidak digunakan untuk mencari "reward" dari uang harian. Informan Bapak J melihat perjalanan dinas yang sekarang dilakukan sebagai bentuk pemborosan. Bapak J menegaskan penjelasan sebelumnya kepada peneliti.

"Nah itu, bagaimana berfikirnya agar jauh lebih efisien. Karena kita sudah digaji dalam 1 bulan, mau bekerja dimana saja, mau di pusat maupun di daerah. atau sudah at cost lah, kalaupun bayar bisa reimburse atau pakai kartu kredit corporate, itu saya yakin gak akan banyak orang mau ke daerah. Artinya gini, ke daerahnya fokus untuk bekerja, gak buat pulang kampung atau apa. ya walaupun masih mending saya bisa jalan-jalan ke sana, masih ada, tapi saya yakin itu berkurang, karena tidak ada. Misal saya 3 hari dapatnya 1 juta atau bahkan 2 juta, gak tahu sebenarnya untuk apa, wong saya hotel sudah, transport sudah, makan kalaupun ini sudah juga."

(Nada obrolan Bapak J seolah mengkritisi kebijakan internal institusinya (otokritik) terkait dengan kegiatan perjalanan dinas)

Pernyataan Bapak J "Misal saya 3 hari dapatnya 1 juta atau bahkan 2 juta, gak tahu sebenarnya untuk apa, wong saya hotel sudah, transport sudah, makan kalaupun ini sudah juga" menegaskan pernyataan sebelumnya bahwa kegiatan perjalanan dinas memang dapat memberikan beberapa benefit kepada pegawai yang melaksanakan perjalan dinas. Dengan terpenuhinya semua kebutuhan di tempat tujuan, perjalanan dinas seharusnya difokuskan untuk bekerja dan tidak untuk memperoleh benefit lain seperti pulang kampung secara gratis. Penjelasan di atas juga menyiratkan bahwa penghasilan satu bulan pegawai Badan Pengelola Dana Amanat sudah mencukupi untuk kebutuhan bulanan yang bersangkutan. Pernyataan Bapak J merefleksikan betapa menariknya kegiatan perjalanan dinas, namun kurang pas dalam hal pendanaannya.

Uang harian perjalanan dinas yang lebih besar daripada uang harian yang berlaku pada PNS juga menjadi daya tarik tersendiri. Informan Bapak J menyadari bahwa usulan "merevolusi" mekanisme perjalanan dinas akan ditentang oleh banyak pihak.

"Ooo...ditentang malahan hahahaha...itu sudah saya sampaikan di rapat. Salah satunya dewas mau presentasi, kan kalau presentasi bisa dari ini arahan. bener gak arahan. maksud saya kita bisa melakukan dengan lebih terkontrol. iya karena memang lumpsum nya lebih besar dibanding PNS. Kalau saya sendiri gede, saya kemaren sempet ke Padang, atau ke Jogja suruh ngajar kuliah umum. Siapa yg nanya, yg nanya 20ribu ya uang itu. Ada yang minta dari kampus UGM."

Pernyataan Bapak J "maksud saya kita bisa melakukan dengan lebih terkontrol. iya karena memang lumpsum nya lebih besar dibanding PNS" sekali lagi menunjukan bahwa uang harian yang bisa dikantongi menjadi daya tarik pegawai untuk melakukan perjalanan dinas. Perjalanan dinas yang kurang terkontrol akan menimbulkan biaya tinggi sedangkan urgensi perjalanan dinas mungkin belum setinggi biaya yang dikeluarkan. Pernyataan Bapak J tersebut merefleksikan bahwa untuk mengurangi senjangan anggaran pada kegiatan perjalanan dinas perlu diperlukan suatu sistem atau mekanisme yang dapat mengontrol urgensi perjalanan dinas.

\section{SIMPULAN DAN SARAN}

\section{Simpulan}

Penelitian ini menemukan fakta bahwa senjangan anggaran dana operasional Badan Pengelola Dana Amanat dapat terjadi karena tingginya partisipasi anggaran dalam penyusunan dana operasional Badan Pengelola Dana Amanat. Keterlibatan para individu dalam penyusunan anggaran dana operasional merupakan model kepemimpinan yang dipilih Direksi karena menginginkan adanya keterlibatan level di bawahnya dalam menyusun anggaran dana operasional Badan Pengelola Dana Amanat. Ini sebagai upaya Direksi melibatkan jajaran di bawahnya dalam proses pencapaian target maupun biaya operasional dalam anggaran organisasi. Dengan partisipasi 
anggaran, bawahan dapat memberikan pengaruh terhadap rencana kinerja keuangan organisasi yang dituangkan dalam anggaran dana operasional Badan Pengelola Dana Amanat.

Senjangan anggaran pada anggaran dana operasional Badan Pengelola Dana Amanat terjadi ketika unit kerja mengusulkan anggaran biaya yang tidak sesuai dengan kebutuhan sebenarnya atau mengusulkan target pendapatan (cakupan kepesertaan) yang kurang sesuai dengan potensi yang dimiliki. Perilaku para individu dalam unit kerja mengecilkan target pendapatan dan meninggikan biaya dari yang seharusnya terjadi berulang atau setiap tahun anggaran. Dalam penelitian ini, salah satu potensi senjangan anggaran pada anggaran dana operasional Badan Pengelola Dana Amanat adalah anggaran perjalanan dinas. Anggaran perjalanan dinas pada unit kerja di kantor pusat Badan Pengelola Dana Amanat diperkirakan terlalu tinggi karena tingginya frekuensi perjalanan dinas yang dilakukan para individu di kantor pusat. Perjalanan dinas tidak hanya digunakan untuk kepentingan dinas, tetapi juga digunakan untuk kepentingan di luar dinas seperti kesempatan memperoleh penghasilan tambahan dan kesempatan jalan-jalan. Adanya uang harian juga dipertanyakan oleh informan karena semua kebutuhan di tempat tujuan perjalanan dinas sudah terpenuhi oleh organisasi.

Dari uraian tersebut di atas, penelitian ini memberikan tambahan bukti empiris bahwa organisasi nirlaba tidak lepas dari senjangan anggaran. Senjangan anggaran dilakukan dengan membuat anggaran bias, di mana terdapat perbedaan antara kebutuhan anggaran sebenarnya dan proposal anggaran yang diajukan oleh unit kerja di pusat dan daerah. Unit kerja menyusun anggaran target pendapatan yang lebih rendah dan anggaran biaya yang dibuat lebih tinggi dari estimasi yang seharusnya.

\section{Saran}

Ada keterbatasan dalam penelitian ini yang berkaitan dengan proses penelitian itu sendiri. Proses wawancara dengan informan terbatas oleh waktu dikarenakan para informan selalu mempunyai tugas perjalanan dinas setiap minggu. Waktu pertemuan dengan para informan praktis hanya bisa dilakukan rata-rata selama 2 hari saja. Keterbatasan lainnya adalah keterbatasan akses dokumen usulan anggaran dari unit kerja di pusat dan daerah. Penelitian berikutnya disarankan untuk meneliti lebih dalam mengenai senjangan anggaran dana operasional yang lebih spesifik. Peneliti juga menyarankan untuk penelitian berikutnya agar dapat mengumpulkan data dari informan di unit kerja di pusat atau daerah sebagai pengusul dan pengguna anggaran. Melibatkan informan dari unit kerja di pusat dan daerah akan dapat menambah data dan informasi tentang bagaimana mereka memahami senjangan anggaran di unit kerja mereka.

\section{DAFTAR RUJUKAN}

Ahmadi, D. D. R. (2014). Metodologi Penelitian Kualitatif. (Rose, Ed.) (2nd ed.). Yogyakarta: ArRuzz Media.

Ajibolade, S. O., \& Akinniyi, O. K. (2013). The Influence of Organisational Culture and Budgetary Participation on Propensity to Create Budgetary Slack In Public Sector Organisations. British Journal of Arts and Social Sciences, 13(I), 69-83.

Brownnell, P. (1982). The Role of Accounting Data in Performance Evaluation, Budgetary Participation, and Organizational Effectiveness. Journal of Accounting Research, 20(1), 12 27.

Colombatto, E. (2001). Discretionary Power, Rent-Seeking and Corruption.

Douglas, P. C., \& Wier, B. (2000). Integrating ethical dimensions into a model of budgetary slack creation. Journal of Business Ethics, 28(3), 267-277.

Faria, J. A. de, \& Silva, S. M. G. da. (2013). The Effects of Information Asymmetry on Budget Slack: An Experimental Research. African Journal of Business Management, Vol. 7(13), 1086-1099.

Garfinkel, H. (1967). Studies in Ethnomethodology (10th ed.). New Jersey: Prentice-Hall, Incl.

Gibson, J. L., Ivancevich, J. M., Donnelly, J. H. J., \& Konopaske, R. (2012). Organizations: 
Behavior, Structure, Processes. (P. Ducham, L. H. Spell, \& J. Beck, Eds.) (14th ed.). New York: McGraw-Hill Companies, Inc.

Griffin, R. W., \& Lopez, Y. P. (2005). “ Bad Behavior ” in Organizations: A Review and Typology for Future Research, 31(6), 988-1005. https://doi.org/10.1177/0149206305279942

Hariningtyas, R. A., \& Aisyah, M. N. (2015). Pengaruh Asimetri Informasi Terhadap Senjangan Anggaran pada Penganggaran Partisipatif dengan Orientasi Etika Sebagai Variabel Moderating. Jurnal Nominal, IV(2), 73-87.

Jaya, M. F. (2012). The Effects Of Budget Participation, Asymmetric Information, Budget Emphasis, And Organizational Commitment On Budgetary Slack In Pemerintah Kota Pasuruan. Jurnal Ilmiah Mahasiswa Universitas Brawijaya, 1(2), 1-29.

Kamayanti, A. (2016). Metodologi Penelitian Kualitatif Akuntansi. (A. D. Mulawarman, Ed.) (I). Jakarta Selatan: Yayasan Rumah Peneleh.

Lincoln, Y. S., \& Guba, E. G. (1985). Naturalistic inquiry. Retrieved from https://www.researchgate.net/publication/256294652_Naturalistic_Inquiry

Liza, N. binti A., Jamil, C. Z. M., \& Nor, N. A. M. (2013). Ethical Antecedents of Dysfunctional Behaviour in Performance Measurement and Control System. Asian Social Science, 9(1), 29-41. https://doi.org/10.5539/ass.v9n1p29

Lukka, K. (1988). Budgetary Biasing In Organizations: Theoritical Framework And Empirical Evidence. Accounting, Organizations, and Society, 13(3), 281-301.

Maharani, A. A. I., \& Ardiana, P. A. (2015). Pengaruh Partisipasi Penganggaran, Asimetri Informasi, dan Budaya Organisasi pada Senjangan Anggaran. E-Jurnal Akuntansi Universitas Udayana, 12(3), 770-785.

Maykut, P., \& Morehouse, R. (1994). Beginning Qualitative Research. A Philosophic and Practical Guide (2nd ed.). London, UK: The Falmer Press.

Moleong, P. D. L. J. (1989). Metodologi Penelitian Kualitatif (33rd ed.). Bandung: PT Remaja Rosdakarya.

Nasehatun, A. (1999). Budget \& Control: Sistem Perencanaan dan Pengendalian Terpadu, Konsep dan Penerapannya. (T. Marganingsih, Ed.) (Edisi 1). Jakarta: PT Gramedia Widiasarana Indonesia.

Neuman, W. L. (2003). Social Research: Qualitative and Quantitative Approaches. Social Research Methods: Qualitative and Quantitative Approaches (7th ed.). London, UK: Pearson.

Rispantyo. (2010). Pengendalian Manajemen: Aspek Keperilakuan Pada Perencanaan Laba dan Penganggaran, 10(1), 59-65.

Schiff, M., \& Lewin, A. Y. (1970). The impact of people on budgets. The Accounting Review, 45(2), 259-268.

Setyorini, C. M. N. E. (2013). Gamesmanship Di Organisasi Nirlaba: Studi Fenomenologi di Universitas Kristen Satya Wacana. Thesis,Program Studi Magister Akuntansi, Fakultas Ekonomi dan Bisnis, Universitas Kristen Satya Wacana.

Stevens, D. E. (2002). The Effects of Reputation and Ethics on Budgetary Slack. Journal Of Management Accounting Research, 14(September), 153-171.

Stoner, A.F.J., dan Wankel, C. (2003). Perencanaan \& Pengambilan Keputusan Dalam Manajemen (2nd ed.). Jakarta: PT Rineka Cipta.

Wibowo. (2007). Manajemen Kinerja (Edisi 1). Jakarta: PT Rajagrafindo Persada.

Young, M. S. (1985). Participative Budgeting: The Effects of Risk Aversion and Asymmetric Information on Budgetary Slack. Journal of Accounting Research, 23(2), 829-842. 